\title{
POLA PEMBELAJARAN EVERYONE IS A TEACHER HERE SEBAGAI ALTERNATIVE PENINGKATAN PROSES BELAJAR AKTIF PESERTA DIDIK
}

\author{
Eva Maghfiroh \\ Institut Agama Islam Syarifuddin Lumajang, Indonesia \\ Email: evajauhari@yahoo.com
}

\begin{abstract}
Efforts to build the Indonesian nation so that the quality of life increases is not an easy and simple matter. Among the big challenges facing this nation is the challenge of education in its broadest sense. One of them is the environment which also colors, influences human growth and development. An education is said to be a process to mature humans. Or in other words education is an attempt to humanize humans. Education is in an important aspect of life, it is closely related to successors whose future must be well prepared, and all of which can only be achieved by education. The everyone is a teacher here method is an easy strategy to obtain large class participation and the responsibility of students. In learning activities, and not necessarily all from the teacher, students just sit in silence and listen to the lessons the teacher delivers, but students can describe and understand each other.
\end{abstract}

Keyword : Everyone Is A Teacher Method, Learning, Students

\begin{abstract}
Abstrak
Upaya membangun bangsa Indonesia agar kwalitas kehidupannya semakin meningkat bukan masalah mudah dan sederhana. Diantara tantangan besar yang dihadapi bangsa ini adalah tantangan pendidikan dalam arti seluas-luasnya. Salah satunya adalah lingkungan yang turut mewarnai, mempengaruhi pertumbuhan dan perkembangan manusia. Sebuah Pendidikan dikatakan sebuah proses untuk mendewasakan manusia. Atau dengan kata lain pendidikan merupakan suatu upaya untuk memanusiakan manusia. Pendidikan berada dalam hal penting dari sebuah kehidupan, ini berkaitan erat dengan penerus yang masa depannya harus dipersiapkan dengan baik, dan semuanya hanya bisa tercapai dengan pendidikan. Metode everyone is a teacher here adalah sebuah Strategi yang mudah untuk memperoleh partisipasi kelas yang besar dan tanggung jawab peserta didik. Dalam kegiatan pembelajaran, dan tidak harus semua dari guru, siswa hanya duduk berdiam diri dan
\end{abstract}


mendengarkan pelajaran yang disampaikan guru, namun peserta didik bisa saling menjelakan dan memahami terhadap peserta didik lainnya.

Kata kunci: Metode Everyone Is A Teacher, Belajar mengajar, Peserta didik

\section{Pendahuluan}

Pendidikan sangat berhubungan erat dengan segala sesuatu yang berkaitan dengan perkembangan manusia mulai perkembangan fisik, pikiran, perasaan, kamauan, sosial, sampai kepada perkembangan iman. Perkembangan ini membuat manusia menjadi lebih baik dan lebih memahami arti dari sebuah pendidikan, membuat manusia meningkatkan hidupnya dan kehidupan alamiah menjadi berbudaya dan bermoral. ${ }^{1}$ Fokus utama dalam dunia pendidikan adalah manusia. Pendidikan bermaksud membantu peserta didik untuk menumbuh kembangkan kemampuan dalam berfikir dalam jiwa kemanusiaannya. ${ }^{2}$ Potensi kemanusiaannya merupakan benih kemungkinan untuk menjadi manusia. Ibarat apa yang kita tanam maka akan tumbuh sesuai apa yang kita tanam dan tidak akan jauh berbeda. ${ }^{3}$

Seiring dengan ini, dapat diambil suatu pengertian bahwa lingkungan secara tidak langsung dapat mendidik manusia dalam bersikap dan tingkah yang salah dan benar sesuai dengan undang undang yang ada dalam masyarakat. Di dalam lingkungan keluarga, orang tua adalah sosok manusia yang ikut andil di dalam mencerdaskan kehidupan bangsa. Secara langsung juga berupaya dalam mencapai cita-cita bangsa,

1 Teguh Wangsa Gandhi, Filsafat Pendidikan, (Jogjakarta: Ar-Ruzz Media, 2011), 65

${ }^{2}$ Khofifah, Z., \& Mahsun, M. (2020). Pendidikan Anak Dalam Keluarga Perspektif Tafsir al-Mishbah Karya M. Quraish Shihab. FIKROH: Jurnal Pemikiran Dan Pendidikan Islam, 13(2), 144-169. https://doi.org/10.37812/fikroh.v13i2.113

${ }^{3}$ Umar Tirtarahardja dan La sula, Pengantar Pendidikan , (Jakarta: Rineka Cipta, 2000),1 
anak adalah generasi penerus dan orang tua juga faktor yang sangat menentukan untuk mempengaruhi sikap dan perbuatan anak. ${ }^{4}$

Abdullah Nashih dalam Sukarno menyatakan dalam bidang pendidikan bukanlah sekedar menghargai manusia, tetapi dengan jelas dan rinci ia menyebutkan sebagai upaya membina umat dan budaya, serta memberlakukan prinsip-prinsip kemuliaan dan peradaban. Dalam tujuan pendidikan agar mampu merubah untuk menjadikan manusia untuk menjadi lebih baik dalam segala bidang, termasuk sikap dan budi pekerti. ${ }^{5}$

Sekolah bertugas mampu mewujudkan tugas dan pokok fungsi pendidikan yang sudah dirumuskan dalam UU Sisdiknas Nomor 20 Tahun 2003 Bab II Pasal 3 Tentang Sistem Pendidikan Nasional yang menjelaskan bahwa: "Pendidikan Nasional berfungsi mengembangkan kemampuan dan membentuk watak serta peradaban bangsa yang bermartabat dalam rangkka mencerdaskan kehidupan bangsa, bertujuan untuk berkembangnya potensi peserta didik agar menjadi manusia yang beriman dan bertakwa kepada Tuhan Yang Maha Esa, berakhlak mulia, sehat, berilmu, cakap, kreatif, mandiri, dan menjadi warga negara yang demokratis dan bertanggung jawab. ${ }^{6}$

Penyelenggaraan pendidikan, siswa, atau peserta didik memegang peran utama. Karena, untuk kepentingan siswa-lah lembaga pendidikan dibentuk, proses pendidikan diselenggarakan, manajemen (pengelolaan) baik pada prosesnya maupun pada lembaganya diterapkan. Semua kegiatan pendidikan, baik yang berkenaan dengan manajemen akademik, layanan pendukung akademik, sumberdaya manusia (kepala

${ }^{4}$ Mahsun, M., \& Koiriyah, M. 2019. Meningkatkan Keterampilan Membaca melalui Media Big Book pada Siswa Kelas IA MI Nurul Islam Kalibendo Pasirian Lumajang. Bidayatuna: Jurnal Pendidikan Guru Mandrasah Ibtidaiyah, 2(01), 60-78. Retrieved

from http://www.ejournal.iaisyarifuddin.ac.id/index.php/bidayatuna/article/view/3 61

5Sukarno. Metodologi Pembelajaran Pendidikan Agama Islam, (Surabaya: el Kaf, 2012),20

6 Departemen Agama RI, Undang-Undang No.20 tahun 2003 tentang Sistem Pendidikan Nasional. 
sekolah, guru, karyawan), aturan yang jelas keluar masuknya keuangan, fasilitas sekolah dan hubungan sekolah dengan lingkungan sekitar, selalu diciptakan agar peserta didik mendapatkan materi pembelajaran yang baik dan mudah dipahami.7 Dengan terpenuhinya hal-hal tersebut, diharapkan bisa mencetak sumber daya manusia baru, generasi penerus bangsa yang berkualitas.

Pembentukan karakter peserta didik harus dibentuk oleh tenaga pendidik, artinya mereka dengan segala karakteristiknya awalnya merupakan lembaran kosong yang akan kita tulis mau di bentuk seperti apa karakter peserta didik ini. Mulai dari pemetaan masalah, kemampuan yang dimiliki, kelebihan dan kekurangan masih masing peserta didik di kelompokkan sesuai kemampuannya, setelah itu kemudian kita arahkan jika mendapatkan kesulitan dalam pembelajaran. ${ }^{8}$ Sehingga dari pendahuan yang sudah disampaikan di awal membutuhkan sebuah metode pembalajaran agar materi yang akan disampaikan mampu di terima dengan baik oleh peserta didik.

\section{Pemahaman Metode Pembelajaran}

Pengertian Metode dalam buku strategi dan metode pembelajaran yang di tulis oleh hatimah adalah sebuah cara yang teratur dan sitematis untuk mencapai target yang di harapkan, cara dalam proses belajar mengajar untuk mencapai pembelajaran yang sudah di siapkan. Di sisi lain hatimah juga menjelaskan bahwa metode berasal dari kata met dan hodes yang berarti melalui. Menurut istilah adalah melangkah di setiap tahapann untuk mencapai tahapan pembelajaran yang sudah direncanakan. ${ }^{9}$

${ }^{7}$ Direktorat Tenaga Kependidikan, Manajemen Kesisiwaan (peserta Didik). (Jakarta: Departemen Pendidikan Nasional dengan Kemitraan Indonesia-Australia, 2007), 1

8 Ibrahim Bafadal, Manajemen Peningkatan Mutu Sekolah Dasar, (Jakarta: Bumi Aksara, 2003), 9

${ }^{9}$ Hatimah, Strategi dan Metode Pembelajaran (Bandung: Adira, 2000), 25. 
Tayar Yusuf Dan Syaiful Anwar, dalam buku Metodologi Pengajaran Agama Dan Bahasa Arab juga menjelaskan bahwa Metode merupakan cara yang di lalui untuk memudahkan peserta didik dalam menerima materi yang akan di sampaikan. Sebagai suatu ilmu yang membicarakan bagaimana cara menyampaikan atau menyajikan bahan pelajaran sehingga dapat diterima, dipahami dan dikuasai oleh anak didik.mempelajari metode saja belumlah menjamin seorang guru akan berhasil dengan baik dalam tugasnya. Tenaga pendidik harus siap dalam menyampaikan pembelajarannya dengan metode yang akan di gunakannya. Dalam hal ini peserta didik akan mampu dan menerima materi pembelajaran tergantung dengan metode yang digunakan serta kemampuan tenaga pendidik tersebut ${ }^{10}$

Dala buku metodologi pendididkan agama islam yang di tulis oleh Ramayulis, dijelaskan bahwa metode merupakan cara yang di buat oleh tenaga pendidik untuk melakukan sebuah hubungan dengan anak didiknyadalam proses belajar mengajar, sdingga bisa mengetahui kemampuan masing masing peseta didik. Dan metode pembelajaran merupakan media untuk proses belajar mengajar untuk menjadi lebih kondusif.. 11

Dari pemahaman diatas, dapat disimpulkan bahwa metode pembelajaran adalah sebuah cara dan strategi untuk memudahkan peserta

10 Tayar Yusuf Dan Syaiful Anwar, Metodologi Pengajaran Agama Dan Bahasa Arab (Jakarta: Raja Grafindo Persada, 1995), 02.

11 Ramayulis, Metodologi Pendidikan Agama Islam ( Jakarta : Kalam Mulia, 2005), 3 dalam link https://www.maxmanroe.com/vid/umum/metode-pembelajaran.html juga di paparkan bahwa metode suatu strategi pembelajaran untuk melakukan proses belajar mengajar dan mengharapkan hasil yang sesuai ataupun memuaskan. Setiap guru musti paham seperti apa karaketr anak didiknya, sehingga penggunaan metode pembelajaran mampu tepat sasaran. Harus ada pemetaan lebih awal sebelum kegiatan belajar mengajar dimulai. Di sinilah tantangan seorang tenaga pendidik dalam menjalankan perannya. 
didik untuk menerima pembelajaran yang efektif dan efisien sesuai yang diinginkan.$^{12}$

\section{Macam-Macam Metode Pembelajaran}

Secara umum terdapat beberapa metode pembelajaran yang bisa dipakai untuk pelaksanaan pembelajaran antara lain:13

Metode Ceramah, Metode Diskusi, Demonstrasi, Metode Resitasi, Every one is a teacher here, Talking stik, Jigsaw, Active Debate, Picture and Picture, Snowball Throwring. Dari metode tersebut, dalam menggunakan harus mengetahui materi dan metode yang akan di gunakan sehingga peserta didik akan mudah dalam menerima materi dan mampu lebih memahaminya jika tenaga pendidik menggunakan metode yang benar . dalam tulisan ini hanya akan fokus terhadap satu metode saja yaitu Metode Everyone Is A Teacher Here.

\section{Sekilas tentang Metode Everyone Is A Teacher Here}

Ramayulis juga menjelasakan bahwa Metode Everyone Is A Teacher Here berasal dari bahasa inggris yang berarti setiap orang adalah guru bisa dari tenaga pendidik dan peserta didik bisa dikatakan sorang guru. Jadi Everyone Is A Teacher Here adalah suatu cara yang memberi waktu pada setiap peserta didik untuk bertindak sebagai pengajar dalam menyampaikan materi terhadap peseta didik lainnya. Dalam proses belajar mengajar tidak harus berasal dari tenaga pendidik, dan siswapun bebas untuk mengemukakan konsepnya untuk dijelaskan didepan temannya dan juga saling bertukar pikiran antar teman lainnya. ${ }^{14}$

Hisyam Zaini, menjelaskan bahwa Everyone Is A Teacher here adalah cara yang sangat sesuai untuk mendapatkan keaktifan dalam sebuah kelas di dalam proses belajar mengajar sehingga guru tidak hanya fokus terhadap materi yang disampaikan. Metode ini memberikan

12 Ismail SM, Strategi Pembelajaran Agama Islam Berbasis PAIKEM (Semarang : Rasail Media Group, 2008), 7

13 Syamsul Hadi, Micro Teaching and team teaching strategi mencetak guru profesional (Lumajang: Cendekia Publishing, 2014), 200-235

14 Ramayulis, Metodologi Pendidikan Agama Islam, (Jakarta: Kalam Mulia, 2005), 112 
kesempatan kepada peserta didik untuk berperan sebagai pengajar bagi temannya. Dengan cara yang di lakukan ini, siswa yang tidak aktif di dalam kelas akan menjadi lebih aktif dalam proses belajar mengajar. ${ }^{15}$

Sebagaimana firman Allah dalam surat Al-Baqoroh ayat 30 menjelaskan bahwa setiap manusia adalah guru.

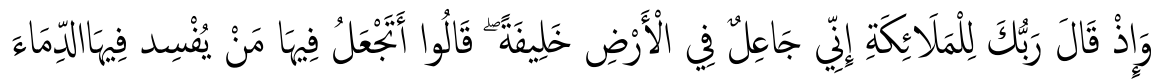

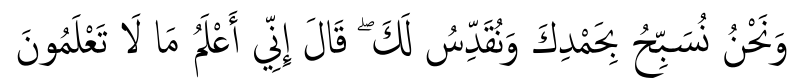

Artinya: Ingatlah ketika Tuhanmu berfirman kepada para malaikat: "Sesungguhnya Aku hendak menjadikan seorang khalifah di muka bumi....16

Menurut Al-Maraghi bahwa ayat diatas menjelaskan diciptakannya nabi Adam As dalam bentuk yang sedemikian rupa disamping kenikmatan memiliki ilmu dan berkuasa penuh mengatur alam semesta serta berfungsi sebagai khalifah Allah di bumi, hal tersebut merupakan nikmat yang paling agung dan harus disyukuri oleh keturunannya dengan cara taat kepada Allah SWT dan tidak ingkar kepada-Nya. Hal ini menunjukkan bahwa setiap manusia memiliki jiwa kepemimpinan yang sangat melekat dalam dirinya oleh karena itu setiap manusia bisa menjadi seorang guru karena guru juga merupakan pemimpin dan teladan bagi siswanya.

Dengan metode ini peserta didik dilatih untuk menjadi pemimpin, ini kelebihan di antaranya dari everyone is a techer here ini, strategi ini juga bisa menjadikan peserta didik berperan sebagai seorang yang menyampaikan materi dan mampu mempertahankan dan memelihara pengetahuan yang didapatkannya. Jika mampu mengembangan materi yang sudah diterimanya dan selalu memperdalam dan mengupdate ilmu yang sudah diterimanya, bisa jadi peserta didik akan lebih kaya pengetahuannya. Dengan cara yang sudah di pelajarinya.

${ }^{15}$ Hisyam Zaini, Bermawy Munthe dan Aryani, Sekar Ayu, Strategi Pembelajaran Aktif. (Yoyakarta : Pustaka Insan Madani dan CTSD UIN Sunan Kalijaga,2008), 60.

${ }^{16}$ QS. Al-Baqoroh: 30 
Dengan kata lain, siswa yang berani menyampaikan ilmunya maka ia bisa lebih mahir dari pada orang yang menerima ilmu yang disampaikannya.

Dari teori diatas dapat disimpulkan bahwa metode Everyone Is A Teacher Here ini tidak hanya fokus terhadap materi pembelajaran yang akan disampaikan oleh tenaga pendidik, namun memberikan kesempatan sebanyak mungkin kepada peserta didik untuk lebih proaktif dalam proses belajar mengajar. Sehingga partisipasi pembelajaran mampu tercipta dengan baik. Di sini tenaga pendidik mempunyai peran dan mengawasi proses belajarnya peserta didik yang satu dengan yang lainnya. Mereka bisa saling bertukar fikiran dan fungsi guru untuk mengarahkannya.

Ismail juga menggambarkan dalam bukunya yang berjudul strategi pembelajaran agama bahwa metode Everyone Is A Teacher Here ini membuat siswa terbiasa untuk menyampaikan pendapatkan dan berani untuk berbicara di depan banyak temannya atau bahasa lainnya melatih mental mereka untuk berani. Kemudian metode ini juga membuat peserta didik untuk konsentrasi penuh terhadap materi yang sedang berlangsung, sehingga mereka selalu fokus dan membuatnya tidak konsentrasi etrhadap materi yang sedang berjalan.$^{17}$

\section{Prinsip-Prinsip Metode Everyone Is A Teacher Here}

Menurut rahayu Dalam metode Everyone Is A Teacher Here yang di tulis di bukunya terdapat tujuh prinsip pokok yang harus diterapkan oleh seorang guru dalam hal metode pengajaran, yaitu:18

1) Memberikan motivasi dan mengetahui minat dan bakat anak didiknya.

2) Tugas dan fungsi pokok sekolah harus diketahui dari awal.

3) Setiap perkembangan dan perubahan baik dalam berfikir dan berkarya guru harus memahaminya.

17 Ismail, Strategi Pembelajaran Agama Berbasis PAIKEM, (Semarang: Rasail Media Group, 2009), 74

${ }^{18}$ Rahayu, Konsep dan Aspek Formal, (Yogyakarta: Graha Ilmu, 2011), 48 
4) Masing masing karakter anak didik berbeda, maka perlu di ketahui.

5) Mengetahui pola piker setiap anak didik.

6) Setiap kegiatan pembelajaran menjadikan suatu hal yang sangat menggembirakan, buka lagi sekolah menjadi hal yang menakutkan.

7) Menjadi pribadi yang bisa ditiru oleh peserta didik, baik dalam bersikap dan bertutur.

Dari paparan di atas bahwa metode merupakan cara ataupun strategi dalam menciptakan sebuah keberhasilan proses belajar mengajar. Memberikan kesempatan etrhadap anak didik untuk mengeksplore kemampuan di depan temannya begitu juga sebaliknya. Selain memahami dan mengerti terhadap materi yang didapatkannya, harapannya mampu merubah sikap, mengembangkan minat dan bakat, prilaku dalam kehidupan yang nyata.

\section{Gambaran dan bentuk bentuk Keaktifan Belajar}

Pengertian Keaktifan Belajar adalah suatu proses pembelajaran yang dilakukan dengan baik dan kondusif. Sedangkan menurut Hamalik keaktifan belajar adalah siswa belajar menjadi lebih aktif, tidak hanya fokus terhadap gurunya saja. ${ }^{19}$

Sudjana dalam buku penilaian hasil proses belajar mengajar bahwa masing masing anak didik memiliki kemampuan yang berbeda sehingga dalam proses belajar mengajarnya pun tidak bisa di samakan dengan anak didik lainnya.. ini bisa kita ketahui di dalam proses pembelajaran, dari keaktifan dan partisipasi dalam pembelajaran. Misalnya dapat diketahui dengan cara ketika anak didik mendengarkan materi yang disampaikan, kemudian ketika mengerjakan soal dan

\footnotetext{
${ }^{19}$ Oemar Hamalik, Kurikulum Dan Pembelajaran, (Jakarta: Bumi Akasra,2008), hal. 90
} 
menyelesaikannya: ${ }^{20}$ keaktifan siswa dapat di ketahui dalam bebrapa hal diantaranya;

1. Dengan mengerjakan tugas yang diberikan

2. Aktif dalam menyelesaikan permasalahan

3. Mengajukan pertanyaan jika menemukan kesulitan dalam menerima materi yang diberikann oleh pengajar.

4. Mengerjakan soal dan menyelesaikannya

5. Menjelaskan materi yang didapatkan

\section{Alur dan Mekanisme Penggunaan Teori Everyone Is A Teacher Here}

Tahapan tahapan Metode Everyone Is A Teacher Here

Adapun tahapan tahapan pelaksanaan strategi Everyone Is A

Teacher Here yang dikemukakan oleh Hisyam Zaini adalah sebagai berikut: ${ }^{21}$

a) Guru memberikan kertas kosong terhadap peserta didik untuk menjawab pertanyaan yang sesuai dengan materi hari ini.

b) Peserta didik menulis pertanyaan di kertas kosong yang sudah di berikan dan dikumpulkan kembali kepada guru dan selanjutnya mengacaknya untuk diserahkan ke peserta didik yang lain.

c) Dipastikan pertanyaan yang ditulis tidak diterima oleh anaknya sendiri, harus pertanyaan yang ditulis peserta didik yang lain, kemudian memikirkan apa yang menjadi jawabannya.

d) Selanjutnya meminta peserta didik untuk membacakan pertanyaan dan jawabnnya di depan teman temannya. Ini juga melatih keberanian mereka untuk berbicara di depan kelas.

${ }^{20}$ N. Sudjana, Penilaian Hasil Proses Belajar Mengajar, (Bandung:Remaja Rosdakarya,2007), 62

${ }^{21}$ Hisyam, Zaini, Strategi Pembelajaran Aktif, (Yogyakarta: Pustaka Insan Madani, 2008), 60 
e) Setelah semua dibaca dan dijelaskan selanjutnya meminta peserta didik lainnya untuk mengomentari dan menambahkan jika perlu ada yang di tambahkan guna mempertajam materi yang sudah dipaparkan.

f) Secara bertahap semua peserta didik akan membacakan pertanyaan dan jawaban yang sudah didapatkan sampai akhir. Dalam hal ini semua peserta didik harus aktif dalam pembelajaran.

\section{Kelebihan dan Kekurangan Metode Everyone Is A Teacher Here}

Selanjutnya Rahayu memaparkan bahwa strategi ini memiliki kekurangan dan kelebihan ketika menggunakannya, diantara kelebihannya yaitu: ${ }^{22}$

1. Metode ini bisa dijadikan proses belajar mengajar terhadap peserta didik

2. Cara ini dapat digunakan secara fleksibel sesuia dengan mata pelajaran yang ada

3. Peserta didik lebih berani mengungkapkan pendapatnya

4. Lebih mampu menganalisis sebuah persoalan dan juga memecahkannya

5. Kemampuan berpendapat selanjutnya bisa ditulis dan di uraikan dalam bentuk essay

6. Setiap materi yang didapatkan kemudian di tarik sebuah kesimpulan yang bisa dilakukan oleh peseta didik

Adapun untuk kelemahan-kelemahan metode Everyone Is $A$ Teacher Here ini sebagai berikut:

1. Diawal pembelajaran guru ataupun tenaga pendidik harus memaparkan materi yang akan dibahas sehingga materi tetap tersampaikan dan fokus terhadap materi awal.

${ }^{22}$ Rahayu, Konsep dan Aspek Formal, (Yogyakarta: Graha Ilmu, 2011), 47 
2. Jumlah peserta didik di dalam kelas tersebut juga akan mempengaruhi jumlah jamm pelajaran. Semakin banyak siswa di kelas tersebut makan membutuhkan waktu banyak untuk menjelaskan pertanyaan dari masing masing peserta didik.

3. Kesulitannya adalah kemampuan berfikir masing masing anak sangat berbeda, disinilah seorang tenaga pendidik harus mampu menulis pertanyaan yang mampu di jaawab oleh semua anka didiknya.

Metode yang paling banyak digunakan adalah metode pembimbing. Maka dari itu, tenaga pendidik harus pandai-pandai menentukan waktu untuk memberikan materi pembelajaran. Metode yang paling banyak digunakan adalah bahwa semua itu bisa menjadi guru. Pola ini Ini akan digunakan dalam kegiatan belajar mengajar. Dan pemilihan strategi belajar harus tepat.

Agar peserta didik dapat belajar dengan baik bukan hanya metode atau strategi yang menjadi tonggak keberhasilan. Ada beberapa faktor pendukung diantaranya lingkungan tempat belajar, dukungan dari keluarga, guru yang sesuai dengan keahliannya. Dari faktor tersebut juga akan mempengaruhi hasil pembelajaran yang sudah diterima peserta didik, melalui tahapan evaluasi yang sudah dipersiapkan.

Pola pembelajaran Everyone Is A Teacher Here yang berguna dalam sumber peningkatan dalam pembelajaran itu meliputi lingkungan sekolah. Faktor metode yang digunakan sangat menentukan dalam proses belajar anak didik untuk meningkatkan kemampuannya dalam mengembangkan pola pembelajarannya untuk mampu berfikir lebih seksama terhadap materi yang sudah diterimanya. Peserta didik tidak akan mampu menerima materi dengan baik jika metode yang digunakan oleh guru tidak sesuai dan tepat sasaran, karena metode ini merupakan sebuah dasar untuk melaksanakan keberlangsungan sebuah proses belajar mengajar yang diterapkan. 


\section{Kesimpulan}

Model pembelajaran Everyone Is A Teacher mampu memberikan keleluasan terhadap peserta didik untuk mengembangkan kemampuannya dalam berfikir dan mengeluarkan gagasan yang di milikinya, dalam peran ini tenaga pendidik menfasilitasi apa yang inginkan oleh peserta didik. Selanjutnya antara peserta didik dengan rekannya mampu berfikir lebih kritis dan tugas seorang guru memberikan kesimpulan secara garis besar sebagai proses akhir.

\section{Daftar Pustaka}

Bafadal,Ibrahim 2003.Manajemen Peningkatan Mutu Sekolah Dasar, Jakarta: Bumi Aksara,

Dimyati, Mudjiono. 1999. Belajar dan Pembelajaran. Jakarta: Rineka Cipta.

Fajri, Em Zul Dan Ratu, Kamus Lengkap Bahasa Indonesia, T.T.P: Difa Publisher,T.T

Hadi, Syamsul. 2014. Micro Teaching and team teaching strategi mencetak guru professional. Lumajang: Cendekia Publishing.

Hamalik, Oemar. 2008. Kurikulum Dan Pembelajaran. Jakarta: Bumi Akasra.

Hari, Jauhari, Muchtar. 2005. Fiqih Pendidikan. Bandung: PT. Rosda Karya.

Hatimah.2000. Strategi dan Metode Pembelajaran. Bandung: Adira.

Ismail. 2009. Strategi Pembelajaran Agama Berbasis PAIKEM. Semarang: Rasail Media Group.

Ismail. SM. 2008. Strategi Pembelajaran Agama Islam Berbasis PAIKEM Semarang : Rasail Media Group.

Khofifah, Z., \& Mahsun, M. 2020. Pendidikan Anak Dalam Keluarga Perspektif Tafsir al-Mishbah Karya M. Quraish Shihab. FIKROH: Jurnal Pemikiran Dan Pendidikan Islam,13(2), 144-169. https://doi.org/10.37812/fikroh.v13i2.113

Mahsun, M., \& Koiriyah, M. 2019. Meningkatkan Keterampilan Membaca melalui Media Big Book pada Siswa Kelas IA MI Nurul Islam Kalibendo Pasirian Lumajang. Bidayatuna: Jurnal Pendidikan Guru Mandrasah Ibtidaiyah, 2(01), 60-78. Retrieved 
from http://www.ejournal.iaisyarifuddin.ac.id/index.php/bidayatu na/article/view/361

Mills. G.E. 2000. A Guide For Teacher Reseacher . London: Printice-Hall International Limited.

Rahayu. 2011. Konsep dan Aspek Formal. Yogyakarta: Graha Ilmu.

Ramayulis. 2005. Metodologi Pendidikan Agama Islam. Jakarta : Kalam Mulia.

Syah, Muhibbin. 2009. Psikologi Belajar. Jakarta: Rajawali.

Sudjana, N. 2007. Penilaian Hasil Proses Belajar Mengajar. Bandung:Remaja Rosdakarya.

Undang-undang RI NO: 20 Tahun 2003 Tentang Sistem Pendidikan Nasional Pasal 1

Zaini, Hisyam. Bermawy Munthe dan Aryani, Sekar Ayu. 2008. Strategi Pembelajaran Aktif. Yoyakarta : Pustaka Insan Madani dan CTSD UIN Sunan Kalijaga. 